Assiut University web-site: $\underline{w w w . a u n . e d u . e g}$

\title{
EVALUATION OF CLINICAL STATUS AND TREATMENT TRIALS IN SHEEP AND GOATS INFESTED WITH EIMERIA SPECIES
}

\author{
HASSAN Y.A.H. MAHMOUD ${ }^{1}$; ALSAGHER O. ALI ${ }^{1}$; RANIA HAMADA ALI ${ }^{2}$ and \\ ADEL ELSYED AHMED ${ }^{2}$ \\ ${ }^{1}$ Division of Infectious Diseases, Animal Medicine Department, Faculty of Veterinary Medicine, South \\ Valley University, Qena 83523, Egypt. \\ ${ }^{2}$ Division of Clinical Laboratory Diagnosis, Animal Medicine Department, Faculty of Veterinary Medicine, \\ South Valley University, Qena 83523, Egypt
}

Received: 25 December 2017; $\quad$ Accepted: 30 January 2018

\begin{abstract}
One hundred forty eight specimens were gathered from sheep and goats, to be inspected for the presence of Eimeria species by fecal analysis. The infection rate was $65.3 \%, 80 \%, 63.6 \%$ and 85.7 in sheep, goats, lambs and kids respectively. In histopathological examination Eimeria and oocysts were distinguished in the villi of epithelium, crypts and lieberkuhn glands. Eighteen animals were deliberately infested and classified into three groups according to the used anticoccidial drugs to estimate their efficacy. Hematological and biochemical analysis were done before and after treatment trials in all animals. In case of sheep, the sulphadimidine (33.3\%) was more effective than amprolium and diclazuril while, the diclazuril has a better effect than amprolium and sulphadimidine $(33.3 \%)$ in case of goats. All treated animals showed improved results in the hemogram and biochemical profile in comparison to untreated animals.
\end{abstract}

Key words: Eimeria, anticoccidial drugs.

\section{INTRODUCTION}

Coccidiosis affect most domestic animals including ovine, caprine, canine, feline, equine, porcine, bovine, lagomorphs and avian, inducing a serious condition on general health status (Coetzer and Justin, 2004). The pervasiveness of Eimeria in sheep and goats is high that could be one hundred percentage in the flock. All Eimeria species share a similar monoxenous life cycle with an internal parasitic and external environmental phase that developed within cells at certain sites of the intestinal mucosa (Arslan et al., 1999).

The best control methods are to avoid the overcrowdings of animals, the reduction of stressors, an adequate nutrition and the use of anticoccidial drugs (Radostits et al., 2000). Anticoccidial drugs could be used to prevent or minimize the outcomes of the clinical cases (Foreyt, 1990; Taylor and Catchpole, 1994). Routine prophylactic medication in the feed and water supplies would usually control the

Corresponding author: Dr. HASSAN Y.A.H. MAHMOUD E-mail address: hayvet2002@yahoo.com

Present address: Division of Infectious Diseases, Animal Medicine Department, Faculty of Veterinary Medicine, South Valley University, Qena 83523, Egypt. disease and allow the development of effective immunity especially in young lambs (Radostits et al., 2000). Anticoccidial drugs that used in control and prevention of coccidiosis include sulphanilamide derivatives, monensin, lasalocid ionophorous antibiotics, amprolium, toltrazuril and diclarzuril (Platzer et al., 2005 and Taylor et al., 2003).

\section{MATERIALS AND METHODS}

\section{Clinical examination}

One hundred forty eight samples were examined for presence of Eimeria species and specimens were gathered from all animals (95 sample from adult sheep, 11 samples from lambs, 35 samples from adult goats and 7 samples from young kids (all animals suffered from diarrhea), from different places in Qena province. Clinical examinations were recorded with especial reference to presences of diarrhea, body condition and mucous membrane examination using Famacha chart (Radostits et al., 2000). Eighteen infected adult animals with Eimeria were selected form farm of faculty of veterinary medicine, South Valley University for exposure to anticoccidial drugs, these animals were divided into 3 groups, and each group contains 6 adult animals ( 3 sheep and 3 goats). 


\section{Fecal samples}

Fecal samples were gathered either directly from anus or from barns from different places in Qena province (from small farms and private). Ninety five samples from adult sheep, 11 samples from lambs, 35 samples from adult goats and 7 samples from young kids.

\section{Blood samples}

Thirty six samples were collected as a whole blood samples from 18 selected animals with interval 14 days pre and post treatment with anticoccidial drugs. For biochemical analyses 54 serum samples were gathered in two occasions in the third and fourteenth day post treatment.

\section{Histopathological examination}

Specimens were settled in $10 \%$ formalin buffer, then the paraffin blocks were primed and five micrometer thickness section were made for histopathological examination, then stained using haematoxylin and eosin (Drury and Wallington, 1980).

\section{Statistical analysis}

Sigma stat software SPSS was utilized to lead a twopath investigation of variance ANOVA and Student's $t$ test to calculate the significance level between and among various treatment groups to test the effects of drug on the oocyst per gram of feces and on body weight. Results were communicated as mean \pm standard error at $\mathrm{P}=0.05$.

\section{Anticoccidial drugs}

Three anticoccidial drugs used to treat the experimental animals; sulphadimidine $33.3 \%$ powder $(100 \mathrm{mg} / \mathrm{kg}$. B.W. given orally daily for 4 days VETWIC. El Nasr pharmaceutical Co.), amprolium $20 \%$ powder $(50 \mathrm{mg} / \mathrm{kg}$. B.W given orally daily for 4 days - ADWIA Co. S.A.E) and diclazuril 1\% solution $(1 \mathrm{mg} / \mathrm{kg}$. B.W given orally daily for 4 days -Diclosol. Pharma SWEDE- Egypt).

\section{RESULTS}

\section{Rate of Eimeria infection}

The rates of Eimeria infection by fecal examination for 148 animals revealed that lambs had a lower infection rate $(63.6 \%)$ than adult sheep $(65.3 \%)$, on the other side; kids had a higher infection rate $(85.7 \%)$ than adult goats $(80 \%)$ (Table 1$)$.

\section{The efficacy of anticoccidial drugs}

Using of sulphadimidine in treatment of coccidiosis, induced a gradual decrease in oocyst count with an efficacy $97.6 \%$ and $85.3 \%$ in sheep and goats respectively, while amprolium has an efficacy $95.6 \%$ and $87.6 \%$ in sheep and goats respectively but, there is a sharp decrease in oocyst count with an efficacy $95.2 \%$ and $100 \%$ in sheep and goat respectively in case of using of diclazuril.

\section{Hematological and biochemical parameters}

Hematological analyses were evaluated for RBCs, WBCs and $\mathrm{Hb}$. The previous parameters were detected two times, one time was done pretreatment with anticoccidial drugs and the second time was done post treatment by 14 days (Table 2). Haematological analyses showed reduction in RBCs and $\mathrm{Hb}$ in diseased animals more than treated, but the leukocytes number was significantly decreased in post-treated sheep and goat than pretreated. Biochemical parameters were done three times, one time was pretreatment and the second and third times were post treatment. The biochemical analysis revealed that an increment in the total protein, albumin, globulin and creatinine in the post treated animals more than diseased ones, there were some alterations in the level of serum ALT and AST (Table $3,4)$.

\section{Clinical and post mortem examination}

Clinical examination were done for 148 animals which suffered from a pale mucus membrane of eye, emaciation, lambs and kids suffered from pasted perineal region with watery diarrhea, dehydration and poor growth rate (Photo $1 \mathrm{~A}, \mathrm{~B}$ ). Post mortem examination was done for one animal died and the lesions were thickness in the mucosa associated with scattered multifocal hemorrhagic areas in the mucosal surface of the intestine. The lesions observed mostly in the distal part of the jejunum, ileum and to lesser extent in the cecum and proximal colon (Photo $1 \mathrm{C}$ ).

\section{Histopathological examination}

Histopathological examination revealed inflammatory reaction mainly infiltration of plasma cells, lymphocytes and eosinophils in the lamina propria. The formative phases of Eimeria were seen in the epithelium of influenced villi, crypts and Lieberkuhn glands. Oocysts were oval and had two layered walls which were seen in the mucosa and occasionally in necrotic-hemorrhagic exudates in the intestinal lumen (Photo $1 \mathrm{D})$. 
Table 1: Infection rate of Eimeria species among all examined animals.

\begin{tabular}{|c|c|c|c|c|}
\hline \multicolumn{2}{|c|}{ Animal species } & $\begin{array}{c}\text { No. of examined } \\
\text { animals }\end{array}$ & $\begin{array}{c}\text { No. of infected } \\
\text { animals }\end{array}$ & $\%$ \\
\hline \multirow{2}{*}{ Sheep } & Female & 75 & 50 & 66.6 \\
\hline & Male & 20 & 12 & 60 \\
\hline \multicolumn{2}{|c|}{ Total adult sheep } & 95 & 62 & 65.3 \\
\hline \multirow{2}{*}{ Goats } & Female & 22 & 18 & 81.8 \\
\hline & Male & 13 & 10 & 76.9 \\
\hline \multicolumn{2}{|c|}{ Total adult goats } & 35 & 28 & 80 \\
\hline \multirow{2}{*}{ Lambs } & Female & 3 & 0 & 0 \\
\hline & Male & 8 & 7 & 87.5 \\
\hline \multicolumn{2}{|c|}{ Total lambs } & 11 & 7 & 63.6 \\
\hline \multirow{2}{*}{ Kids } & Female & 2 & 2 & 100 \\
\hline & Male & 5 & 4 & 80 \\
\hline \multicolumn{2}{|c|}{ Total kids } & 7 & 6 & 85.7 \\
\hline \multicolumn{2}{|c|}{ Total } & 148 & 103 & 69.6 \\
\hline
\end{tabular}

Table 2: Hematological parameters for pre and post treatment of selected sheep and goat.

\begin{tabular}{|c|c|c|c|c|c|c|c|c|c|c|c|c|}
\hline \multirow[t]{3}{*}{ Parameters } & \multicolumn{4}{|c|}{ Group A } & \multicolumn{4}{|c|}{ Group B } & \multicolumn{4}{|c|}{ Group C } \\
\hline & \multicolumn{2}{|c|}{ Sheep } & \multicolumn{2}{|c|}{ Goat } & \multicolumn{2}{|c|}{ Sheep } & \multicolumn{2}{|c|}{ Goat } & \multicolumn{2}{|c|}{ Sheep } & \multicolumn{2}{|c|}{ Goat } \\
\hline & Pre & Post & Pre & Post & Pre & Post & Pre & Post & Pre & Post & Pre & Post \\
\hline $\mathrm{RBCs} \times 10^{6} / \mathrm{mm}^{3}$ & $\begin{array}{c}9.84 \\
\pm 0.38\end{array}$ & $\begin{array}{c}10.95 \\
\pm 1.36^{*}\end{array}$ & $\begin{array}{l}13.52 \\
\pm 2.88\end{array}$ & $\begin{array}{l}15.49 \\
\pm 2.95^{*}\end{array}$ & $\begin{array}{l}11.16 \\
\pm 2.34\end{array}$ & $\begin{array}{c}12.57 \\
\pm 1.95^{*}\end{array}$ & $\begin{array}{l}12.23 \\
\pm 2.48\end{array}$ & $\begin{array}{c}16.43 \\
\pm 1.74^{*}\end{array}$ & $\begin{array}{l}10.05 \\
\pm 3.21\end{array}$ & $\begin{array}{c}12.25 \\
\pm 1.83^{*}\end{array}$ & $\begin{array}{l}18.50 \\
\pm 1.32\end{array}$ & $\begin{array}{l}18.80 \\
\pm 1.82\end{array}$ \\
\hline WBCs $\times 10^{3} / \mathrm{mm}^{3}$ & $\begin{array}{l}10.58 \\
\pm 5.28\end{array}$ & $\begin{array}{c}8.45 \\
\pm 2.89^{*}\end{array}$ & $\begin{array}{c}6.56 \\
\pm 2.35\end{array}$ & $\begin{array}{c}8.58 \\
\pm 1.21^{*}\end{array}$ & $\begin{array}{c}7.41 \\
\pm 1.58\end{array}$ & $\begin{array}{c}10.46 \\
\pm 2.38^{*}\end{array}$ & $\begin{array}{c}8.45 \\
\pm 1.34\end{array}$ & $\begin{array}{c}7.98 \\
\pm 2.55\end{array}$ & $\begin{array}{l}12.26 \\
\pm 5.50\end{array}$ & $\begin{array}{c}9.05 \\
\pm 2.29^{*}\end{array}$ & $\begin{array}{c}9.60 \\
\pm 4.16\end{array}$ & $\begin{array}{c}6.95 \\
\pm 2.45^{*}\end{array}$ \\
\hline Hb. g/dl & $\begin{array}{c}10.5 \\
\pm 1.35\end{array}$ & $\begin{array}{c}12.4 \\
\pm 1.60^{*}\end{array}$ & $\begin{array}{c}9.8 \\
\pm 0.45\end{array}$ & $\begin{array}{c}10.3 \\
\pm 0.95^{*}\end{array}$ & $\begin{array}{c}11.1 \\
\pm 1.21\end{array}$ & $\begin{array}{c}12.63 \\
\pm 2.10^{*}\end{array}$ & $\begin{array}{l}10.36 \\
\pm 0.32\end{array}$ & $\begin{array}{c}10.5 \\
\pm 0.1^{*}\end{array}$ & $\begin{array}{l}10.78 \\
\pm 2.56\end{array}$ & $\begin{array}{c}9.33 \\
\pm 0.40^{*}\end{array}$ & $\begin{array}{c}13.6 \\
\pm 0.98\end{array}$ & $\begin{array}{c}11.58 \\
\pm 0.92 \%\end{array}$ \\
\hline
\end{tabular}

* Significant different from mean value at $\mathrm{P}<0.05$

RBCs: Red Blood Cell Count

WBCs: White Blood Cell Count

$\mathrm{Hb}$ : Hemoglobin Concentration

Table 3: Biochemical parameters in pre and post treatment of sheep

\begin{tabular}{|c|c|c|c|c|c|c|c|c|c|}
\hline \multirow{4}{*}{ Animal } & \multicolumn{3}{|c|}{ Group A } & \multicolumn{3}{|c|}{ Group B } & \multicolumn{3}{|c|}{ Group C } \\
\hline & \multicolumn{3}{|c|}{ Sheep } & \multicolumn{3}{|c|}{ Sheep } & \multicolumn{3}{|c|}{ Sheep } \\
\hline & \multirow{2}{*}{ Pre } & \multicolumn{2}{|c|}{ Post } & \multirow{2}{*}{ Pre } & \multicolumn{2}{|c|}{ Post } & \multirow{2}{*}{ Pre } & \multicolumn{2}{|c|}{ Post } \\
\hline & & $3^{\text {rd }}$ day & $14^{\text {th }}$ day & & $3^{\text {rd }}$ day & $14^{\text {th }}$ day & & $3^{\text {rd }}$ day & $14^{\text {th }}$ day \\
\hline $\begin{array}{c}\text { Total protein } \\
\mathrm{g} / \mathrm{dl}\end{array}$ & $\begin{array}{c}5.9 \\
\pm 1.9 \\
\end{array}$ & $\begin{array}{c}5.5 \\
\pm 1.1 \\
\end{array}$ & $\begin{array}{c}5.5 \\
\pm 1.1 \\
\end{array}$ & $\begin{array}{c}5.5 \\
\pm 1.1 \\
\end{array}$ & $\begin{array}{c}5.2 \\
\pm 1.2 \\
\end{array}$ & $\begin{array}{c}5.8 \\
\pm 0.2^{*} \\
\end{array}$ & $\begin{array}{c}5.2 \\
\pm 1.2\end{array}$ & $\begin{array}{c}5.2 \\
\pm 1.2 \% \\
\end{array}$ & $\begin{array}{c}5.1 \\
\pm 1.2^{*} \\
\end{array}$ \\
\hline Albumin $\mathrm{g} / \mathrm{dl}$ & $\begin{array}{c}3.5 \\
\pm 0.3 \\
\end{array}$ & $\begin{array}{c}3.3 \\
\pm 0.2\end{array}$ & $\begin{array}{c}3.3 \\
\pm 0.2 \\
\end{array}$ & $\begin{array}{c}3.3 \\
\pm 0.2 \\
\end{array}$ & $\begin{array}{c}3.4 \\
\pm 0.3\end{array}$ & $\begin{array}{c}3.4 \\
\pm 0.3\end{array}$ & $\begin{array}{c}3.4 \\
\pm 0.3\end{array}$ & $\begin{array}{c}3.6 \\
\pm 0.4\end{array}$ & $\begin{array}{c}3.7 \\
\pm 0.0^{*}\end{array}$ \\
\hline Globulin $\mathrm{g} / \mathrm{dl}$ & $\begin{array}{c}2.4 \\
\pm 2.2 \\
\end{array}$ & $\begin{array}{c}2.2 \\
\pm 0.9 \\
\end{array}$ & $\begin{array}{c}2.2 \\
\pm 0.9 \\
\end{array}$ & $\begin{array}{c}2.2 \\
\pm 0.9 \\
\end{array}$ & $\begin{array}{r}1.8 \\
\pm 1.2 \\
\end{array}$ & $\begin{array}{c}2.3 \\
\pm 0.4^{*} \\
\end{array}$ & $\begin{array}{r}1.8 \\
\pm 1.2 \\
\end{array}$ & $\begin{array}{r}1.6 \\
\pm 1^{*} \\
\end{array}$ & $\begin{array}{r}1.5 \\
\pm 1.2^{*} \\
\end{array}$ \\
\hline $\begin{array}{c}\text { Creatinine } \\
\mathrm{mg} / \mathrm{dl}\end{array}$ & $\begin{array}{l}0.75 \\
\pm 0.3 \\
\end{array}$ & $\begin{array}{c}0.9 \\
\pm 0.2 \\
\end{array}$ & $\begin{array}{c}0.9 \\
\pm 0.2 \\
\end{array}$ & $\begin{array}{c}0.9 \\
\pm 0.2 \\
\end{array}$ & $\begin{array}{c}1.4 \\
\pm 0.4 \\
\end{array}$ & $\begin{array}{c}1.6 \\
\pm 0.3 \\
\end{array}$ & $\begin{array}{c}1.4 \\
\pm 0.4 \\
\end{array}$ & $\begin{array}{c}0.7 \\
\pm 0.2^{*} \\
\end{array}$ & $\begin{array}{c}0.6 \\
\pm 0.2^{*} \\
\end{array}$ \\
\hline AST U/L & $\begin{array}{l}23.9 \\
\pm 9.6 \\
\end{array}$ & $\begin{array}{c}27.2 \\
\pm 21.9 \\
\end{array}$ & $\begin{array}{c}27.2 \\
\pm 21.9 \\
\end{array}$ & $\begin{array}{c}27.2 \\
\pm 21.9 \\
\end{array}$ & $\begin{array}{c}22.2 \\
\pm 16.3 \\
\end{array}$ & $\begin{array}{c}60.5 \\
\pm 11.7^{*} \\
\end{array}$ & $\begin{array}{c}22.2 \\
\pm 16.3 \\
\end{array}$ & $\begin{array}{c}20.8 \\
\pm 18.9^{*} \\
\end{array}$ & $\begin{array}{c}14.9 \\
\pm 18.9 \% \\
\end{array}$ \\
\hline ALT U/L & $\begin{array}{c}11.1 \\
\pm 7\end{array}$ & $\begin{array}{c}6.6 \\
\pm 4.2\end{array}$ & $\begin{array}{c}6.6 \\
\pm 4.2\end{array}$ & $\begin{array}{c}6.6 \\
\pm 4.2\end{array}$ & $\begin{array}{c}8 \\
\pm 2.6\end{array}$ & $\begin{array}{c}4.9 \\
\pm 2.4^{*}\end{array}$ & $\begin{array}{c}8 \\
\pm 2.6\end{array}$ & $\begin{array}{c}8.3 \\
\pm 2.4\end{array}$ & $\begin{array}{c}10.9 \\
\pm 3.5^{*}\end{array}$ \\
\hline
\end{tabular}

* Significant different from mean value at $\mathrm{P}<0.05$ 
Table 4: Biochemical parameters in pre and post treatment of goat.

\begin{tabular}{|c|c|c|c|c|c|c|c|c|c|}
\hline \multirow{4}{*}{ Animal } & \multicolumn{3}{|c|}{ Group A } & \multicolumn{3}{|c|}{ Group B } & \multicolumn{3}{|c|}{ Group C } \\
\hline & \multicolumn{3}{|c|}{ Goat } & \multicolumn{3}{|c|}{ Goat } & \multicolumn{3}{|c|}{ Goat } \\
\hline & \multirow{2}{*}{ Pre } & \multicolumn{2}{|c|}{ Post } & \multirow{2}{*}{ Pre } & \multicolumn{2}{|c|}{ Post } & \multirow{2}{*}{ Pre } & \multicolumn{2}{|c|}{ Post } \\
\hline & & $3^{\text {rd day }}$ & $14^{\text {th }}$ day & & $3^{\text {rd day }}$ & $14^{\text {th }}$ day & & $3^{\text {rd day }}$ & $14^{\text {th }}$ day \\
\hline $\begin{array}{c}\text { Total } \\
\text { protein } \mathrm{g} / \mathrm{dl}\end{array}$ & $\begin{array}{c}5.8 \\
\pm 0.8\end{array}$ & $\begin{array}{c}5.2 \\
\pm 1.2^{*}\end{array}$ & $\begin{array}{c}5.1 \\
\pm 1.2^{*}\end{array}$ & $\begin{array}{c}4.9 \\
\pm 0.4\end{array}$ & $\begin{array}{c}4.66 \\
\pm 0.2^{*}\end{array}$ & $\begin{array}{c}4.7 \\
\pm 0.2 *\end{array}$ & $\begin{array}{c}4.6 \\
\pm 0.8\end{array}$ & $\begin{array}{c}5.6 \\
\pm 0.6^{*}\end{array}$ & $\begin{array}{c}5.6 \\
\pm 0.1^{*}\end{array}$ \\
\hline $\begin{array}{l}\text { Albumin } \\
\text { g/dl }\end{array}$ & $\begin{array}{c}3.5 \\
\pm 0.1 \\
\end{array}$ & $\begin{array}{c}3.6 \\
\pm 0.4 \\
\end{array}$ & $\begin{array}{r}3.7 \\
\pm 0.0^{*} \\
\end{array}$ & $\begin{array}{c}3.9 \\
\pm 0.4 \\
\end{array}$ & $\begin{array}{c}3.2 \\
\pm 0.2 \\
\end{array}$ & $\begin{array}{c}3.1 \\
\pm 0.3^{*} \\
\end{array}$ & $\begin{array}{c}3.9 \\
\pm 0.3 \\
\end{array}$ & $\begin{array}{c}3.7 \\
\pm 0.2^{*} \\
\end{array}$ & $\begin{array}{c}3.9 \\
\pm 0.3 \\
\end{array}$ \\
\hline $\begin{array}{c}\text { Globulin } \\
\mathrm{g} / \mathrm{dl}\end{array}$ & $\begin{array}{c}2.3 \\
\pm 0.8 \\
\end{array}$ & $\begin{array}{r}1.6 \\
\pm 1^{*} \\
\end{array}$ & $\begin{array}{r}1.5 \\
\pm 1.2^{*} \\
\end{array}$ & $\begin{array}{r}1.5 \\
\pm 0.7 \\
\end{array}$ & $\begin{array}{c}1.4 \\
\pm 0.1 \\
\end{array}$ & $\begin{array}{r}1.6 \\
\pm 0.3 \\
\end{array}$ & $\begin{array}{r}0.6 \\
\pm 1.0 \\
\end{array}$ & $\begin{array}{c}1.8 \\
\pm 0.55^{*} \\
\end{array}$ & $\begin{array}{c}1.7 \\
\pm 0.4^{*} \\
\end{array}$ \\
\hline $\begin{array}{c}\text { Creatinine } \\
\mathrm{mg} / \mathrm{dl}\end{array}$ & $\begin{array}{r}0.8 \\
\pm 0.1 \\
\end{array}$ & $\begin{array}{r}0.7 \\
\pm 0.2^{*} \\
\end{array}$ & $\begin{array}{r}0.6 \\
\pm 0.2^{*} \\
\end{array}$ & $\begin{array}{r}0.7 \\
\pm 0.1 \\
\end{array}$ & $\begin{array}{c}0.6 \\
\pm 0.4 \\
\end{array}$ & $\begin{array}{r}0.6 \\
\pm 0.38 \\
\end{array}$ & $\begin{array}{c}1.0 \\
\pm 0.4 \\
\end{array}$ & $\begin{array}{c}0.8 \\
\pm 0.1^{*} \\
\end{array}$ & $\begin{array}{r}0.6 \\
\pm 0.4^{*} \\
\end{array}$ \\
\hline AST U/L & $\begin{array}{l}42.6 \\
\pm 4.7 \\
\end{array}$ & $\begin{array}{c}20.8 \\
\pm 18.9^{*} \\
\end{array}$ & $\begin{array}{r}14.9 \\
\pm 18.9^{*} \\
\end{array}$ & $\begin{array}{r}19.3 \\
\pm 13.9 \\
\end{array}$ & $\begin{array}{l}23.5 \\
\pm 19 \\
\end{array}$ & $\begin{array}{r}9.7 \\
\pm 9.8 * \\
\end{array}$ & $\begin{array}{r}9.9 \\
\pm 6.4 \\
\end{array}$ & $\begin{array}{r}3.5 \\
\pm 0.0^{*} \\
\end{array}$ & $\begin{array}{r}14.2 \\
\pm 11.3 \\
\end{array}$ \\
\hline ALT U/L & $\begin{array}{c}6.6 \\
\pm 4.6\end{array}$ & $\begin{array}{c}8.3 \\
\pm 2.4 \\
\end{array}$ & $\begin{array}{c}10.9 \\
\pm 3.5^{*}\end{array}$ & $\begin{array}{c}4.1 \\
\pm 1.5 \\
\end{array}$ & $\begin{array}{c}7.3 \\
+4.98^{*} \\
\end{array}$ & $\begin{array}{c}3 \\
\pm 2.5^{*} \\
\end{array}$ & $\begin{array}{c}4.9 \\
\pm 7.4\end{array}$ & $\begin{array}{c}5.7 \\
\pm 4.4\end{array}$ & $\begin{array}{c}5.6 \\
\pm 3.4 \\
\end{array}$ \\
\hline
\end{tabular}

* Significant different from mean value at $\mathrm{P}<0.05$
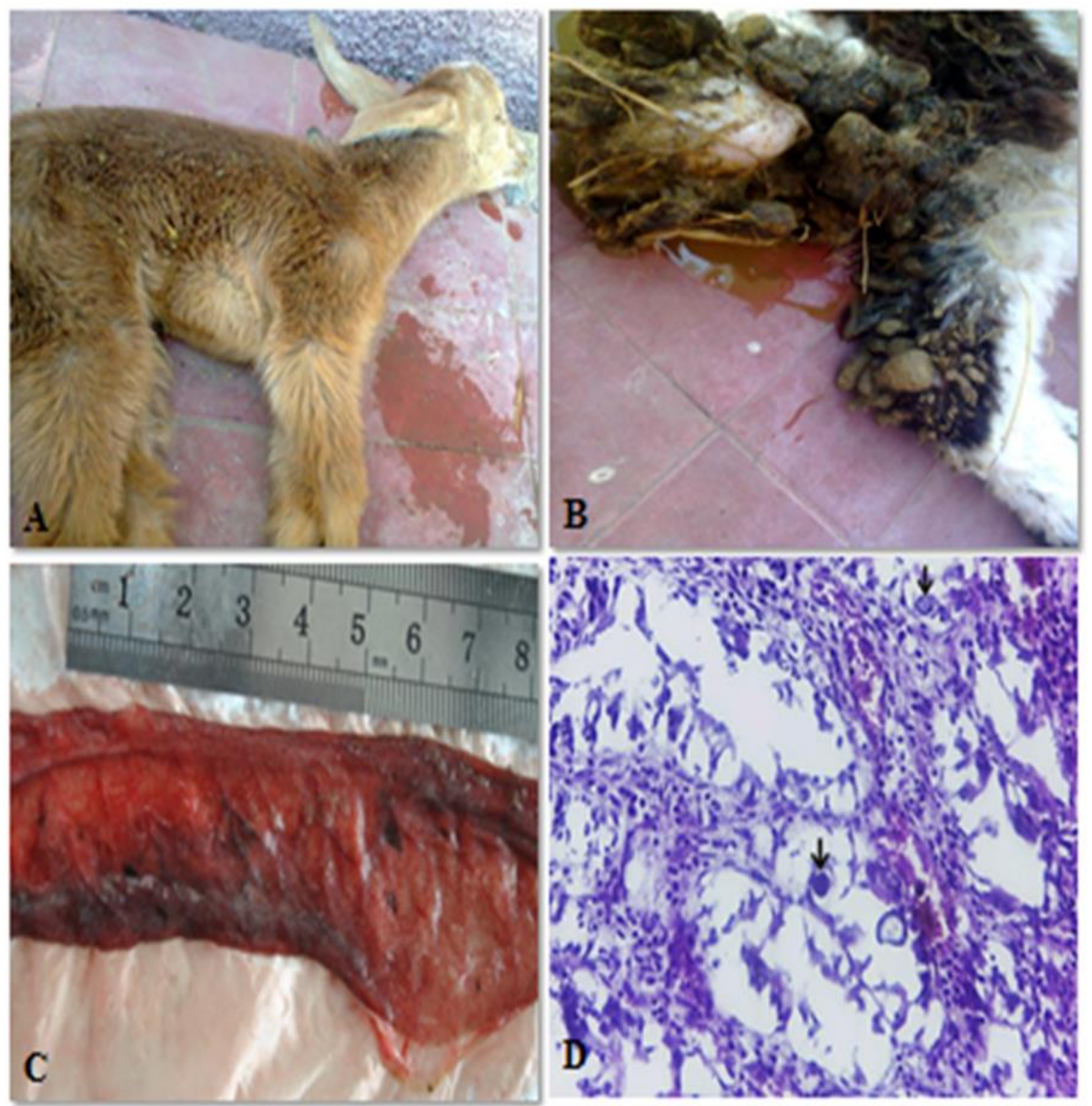

Photos 1: A and B: Diarrhea and dehydration in lamb and kid affected with coccidiosis. C: Multifocal necrohaemorrhagic areas were seen in the distal part of jujenum of lamb infected with coccidiosis. D: Different developmental stages of Eimeria and oocysts were seen in the epithelium of affected intestinal villi. 


\section{DISCUSSION}

Anticoccidial drugs had a significant variation in their effects in sheep treated with sulphadimidine, that having the highest percentage of efficacy $97.6 \%$ followed by amprolium $95.6 \%$ and diclazuril $95.2 \%$; similar findings in buffalo calves (Ghanem et al., 2008; Guo et al., 2007). Sulphadimidine had a little efficiency in controlling goat coccidian infestation than amprolium (Abakar, Ghanem and Abd El-Raof, 2005), in contrary of diclazuril that has a higher efficacy against coccidiosis in goat (Ruiz et al., 2012).

Haematological examination in ailing animals uncovered a diminishment in RBCs and $\mathrm{Hb}$, which could be attributed to hemorrhagic enteritis associated with coccidiosis (Deghidy et al., 1984). Treated animals with sulphadimidine and amprolium revealed a significant increase in total RBCs and $\mathrm{Hb}$. The leukocytes number was significantly decreased in post-treated sheep and goat than pretreated; those changes could be as a result of recovery from disease (Amulya et al., 2014, Ahmed et al., 2006).

The biochemical analysis revealed an increase in the total protein, albumin and globulin in the pros-trated animals, because the gastro-intestinal parasitism attributed in plasma leakage through the gut which reflected on the protein level (Radostits et al., 1994,Tanwar and Mishra 2001), in addition to the secondary bacterial infection and the malabsorption syndrome occurring subsequently to the damage of intestinal mucosa and the loss of epithelial surface which lead to decrease in the protein level (Catchpole and Gregory, 1985).

The level of creatinine in post treated group was increased that could be due to the toxic effect of drugs as nephropathy and hypersensitivity leading to increasing the level of urea and creatinine (Goodman and Gilman 1965). There were some alterations in the level of serum AST and ALT that could be attributed to the liver might be adversely affected by Eimeria and anticoccidial drugs (Ghanem and Abd-Elraof, 2005).

Histopathological examination showed a thickened mucosa with scattered small hemorrhagic patches, the developmental stages of Eimeria and oocysts were detected in the epithelium of villi, crypts and necrotic-hemorrhagic exudates in the intestinal lumen. These results in agreement with (Ghanem et al., 2008). The intestinal mucosa of the untreated kids was characterized by hypertrophy of the intestinal villi that were severely infected with large number of the developmental stages of Eimeria species. The mucosal blood vessels were congested with blood and the lamina propria was infiltrated with leucocytes particularly lymphocytes and oesinophils. Large area of the intestinal mucosa showed desquamation of the lining epithelia cells which seen in the intestinal lumen mixed with necrotic debris and inflammatory cells, similarly to (Gab-Allah, 1990).

\section{REFERENCE}

Abakar, A.D.; Seri, H.I.; Ismail, A.A. and Musa, H.H. (2005): Comparative efficacy of selected anticoccidial drugs in Ambarorow Sheep naturally infected with enteric Coccidia in South Darfur, Sudan. The Sudan J. Vet. Res, 20: 61-67.

Ahmed, M.I.; Ambali, A.G. and Baba, S.S. (2006): Haematological and biochemical responses of Balami sheep to experimental Fasciola gigantica infection. Journal of Food, Agriculture and Enviornment, 42: 71-74.

Amulya, G.; Sudharani, R.; Ismail Shareef, M. and Gopinath, S.M. (2014): Haemato-Biochemical changes in sheep suffering from gastrointestinal parasitism. Indian J. Field Vets., 2: 20-22.

Arslan, M.O.; Umur, S. and Kara, M. (1999): The prevalence of coccidianspecies in sheep in Kars province of Turkey. Tropical Animal Health and Production, 31: 161-165.

Catchpole, S. and Gregory, M.W. (1985): The pathogenicity of coccidium Eimeria crandllis in laboratory lambs. Parasite., 911: 45-52.

Coetzer, J. and Justin, R. (2004): Infectious Diseases of Livestock. $2^{\text {nd }}$ Ed., Oxford University press. P., 319- 331.

Deghidy, N.S.; Hilali, M. and Hassanin, M.A. (1984): Conccidiosis of sheep in Egypt. Assuit, Vet. M .J., 26: 165-174.

Drury, R.A.B. and Wallington E.A. (1980): Preparation and fixation of tissues. In. Carleton's Histological Technique. $5^{\text {th }}$ Ed. Oxford University Press, P. 41-54.

Foreyt, W.J.; Hancock, D. and Wescott, R.B. (1986): Prevention and control of coccidiosis in goats with decoquinate. Am. J. Vet. Res., 47: 333335.

Gab-Allah, M.S.A. (1990): Coccidiosis in angloNobian goats in Gemmiza. Zag. Vet. J., 182: 204-214.

Ghanem, M.; Mervat, E. Radwaan; Abdel Moneim, M. Moustafa and Mohamed, H. Ebeid (2008): Comparative therapeutic effect of toltrazuril, sulphadimidine and amprolium on Eimeria bovis and Eimeria zuernii given at different times following infection in buffalo calves Bubalus bubalis. Preventive Veterinary Medicine, 84:161-170.

Ghanem Mohamed, M.; Afafa, D.A. and Mohamed, Y. Ramadan (2009): Clinical, biochemical and histopathological study on parasitic gastroenteritis associated with caprine coccidiosis: comparative effect of toltrazuril and propolis. Lucrări științifice, 11: 565-580. 
Ghanem, M.M. and Abd El-Raof, Y.M. (2005): Clinical and haemato-biochemical studies on Lamb coccidiosis and changes following Amprolium and sulphadimthoxine therapy. Benha Vet. Med. J., 16: 286-300

Goodman, L.S. and Gilman, A. (1965): The pharmacological basis of therapeutics, $3^{\text {rd }} \mathrm{Ed}$., McMillan. NewYork.

Guo, F.C.; Suo, X.; Zhang, G.Z. and Shen, J.Z. (2007): Efficacy of decoquinate against drug sensitive laboratory strains of Eimeria tenella and field isolates of Eimeria spp. in broiler chickens in China. Veterinary parasitology, 147: 239-245.

Platzer, B.; Prosl, H.; Cieslicki, M. and Joachim, A. (2005): Epidemiology of Eimeria infections in an Austrian milking sheep flock and control with diclazuril. Vet. Parasitol., 129: 1-9.

Radostits, O.M.; Blood, D.C. and Gray, C.C. (2000): Veterinary medicine a textbook of the diseases of cattle, sheep, pigs, goats and horses. $8^{\text {th }}$ Ed., Philadelphia, USA.
Radostits, O.M.; Blood, D.C. and Gay, C.C. (1994): Veterinary medicine. $8^{\text {th }}$ Ed., Bailliere Tindal, London, P.1223-1272.

Ruiz, A.; Aránzazu, C. Guedes; María, C. Muñoz; José, M. Molina; Carlos Hermosilla; Sergio Martín (2012): Control strategies using diclazuril against coccidiosis in goat kids. Parasitol. Res., 110:2131-2136.

Tanwar, R.K. and Mishra, S. (2001): ClinicoHaemato-biochemical studies on intestinal helminthiasis in poultry. Veterinary Practitioner, 2: 137-140.

Taylor, M.A. and Catchpole, J. (1994): Coccidiosis of ruminants. A review in Applied Parasitology, 35: 73-86.

Taylor, M.A.; Catchpole, J.; Marshall, J.; Marshall, R.N. and Hoeben, D. (2003): Histopathological observations on the activity of diclazuril Vecoxan against the endogenous stages of Eimeria crandallis in sheep. Vet. Parasitol., 1164: 305-314.

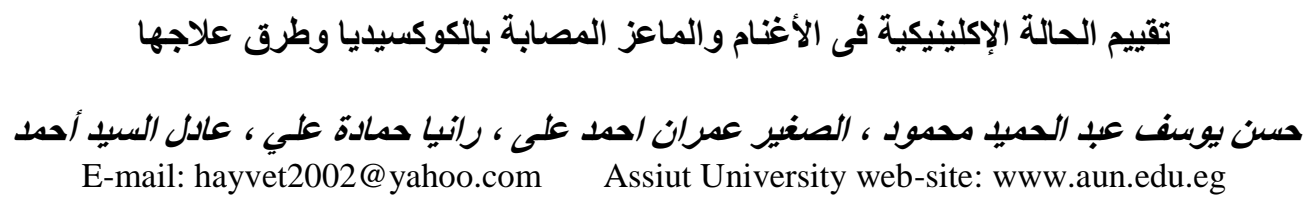

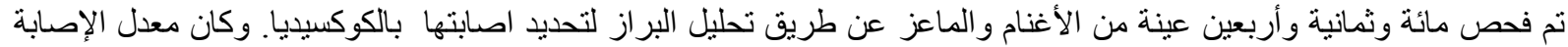

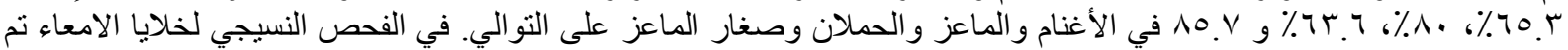

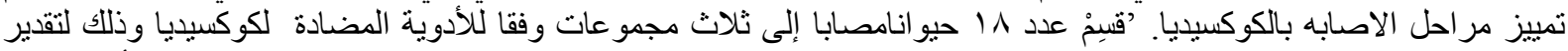

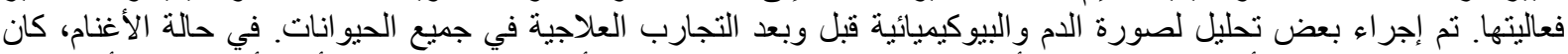

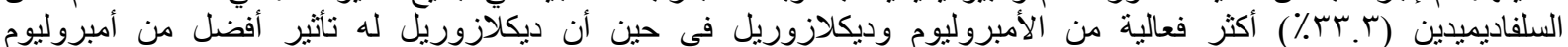

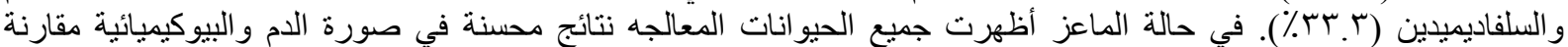
بالحيو انات غير المعالجة. 